Research Article

\title{
Evaluation of in- vitro Anti-inflammatory Potential of Grevillea robusta A. Cunn, EX R.BR. Leaves
}

\author{
Samanta Jhuma ${ }^{1 *}$, Kumar Vineet ${ }^{2}$ \\ 1. Shree Dev Bhoomi Institute of Pharmacy, Dehradun, Uttarakhand, India. \\ 2. Dev Bhoomi Institute of Pharmacy and Research, Dehradun, Uttarakhand, India. \\ *Corresponding author's E-mail: jhmsamanta02@gmail.com
}

Received: 04-03-2021; Revised: 18-04-2021; Accepted: 26-04-2021; Published on: 15-05-2021.

\begin{abstract}
Synthetic Non-steroidal anti-inflammatory drugs (NASAIDs) are the choice of drug for inflammation. NASAIDs caused severe side effects like hyperacidity, gastric ulcer and so on. To avoid the side effects of NASAIDs, there is an urgent need for searching new molecule from natural origin. Present study is therefore aimed to explore Grevillea robusta A. Cunn, ex R.Br. Family proteaceae leaves for anti-inflammatory activity. Microscopic measurement (fibre length and width), Ash values and extractive values of Grevillea robusta leaves were determined to set the pharmacognostic standards. Chemical constituents were evaluated through chemical tests. The Ethanol extract of Grevillea robusta leaves (GRLE)) were subjected to evaluate in-vitro anti-inflammatory activity through HRBC method and Heat induced haemolytic method. The leaves of Grevillea robusta showed significant anti-inflammatory activity. The Ethanol extract (GRLE) showed significant anti-inflammatory activities. GRLE was found to contain polyphenols as chemical constituents which was the basis of anti-inflammatory activity. On the basis of result we can conclude that Ethanol extract of leaves of Grevillea robusta has good anti-inflammatory activity. GRLE could be used for treatment of inflammation.
\end{abstract}

Keywords: Grevillea robusta, leaves, anti-inflammatory activity.

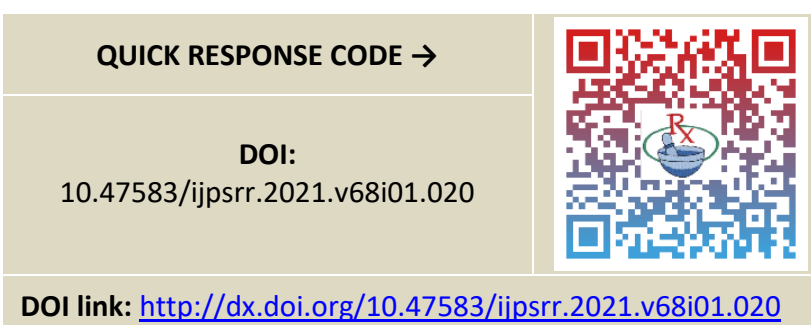

\section{INTRODUCTION}

nflammation is part of the complex biological response of tissues to harmful stimuli, such as, damaged cells or irritants. The classical sign of acute inflammation are pain, heat, redness, swelling, and loss of function. It is characterized by redness, swollen joints, joint pain, its stiffness and loss of joint function ${ }^{1,2}$. Inflammation is a protective attempt by the organism to remove the injurious stimuli and to initiate the healing process.

Inflammation is currently treated by NSAIDs. Unfortunately these drugs cause increased gastric and duodenal ulcer and elevate the risk of blood clot resulting in heart attacks and strokes ${ }^{3}$.Therefore, the developments of potent anti-inflammatory drugs from the natural products are now under considerations. Natural products are rich source for discovery of new drugs because of their chemical diversity. A natural product from medicinal plants plays a major role to cure many diseases associated with inflammation. The conventional drug available in the market to treat inflammation produces various sideeffects.
Grevillea robusta timber was widely used for external window joinery, as it is resistant to wood rot. It has been used in the manufacture of furniture, cabinetry, and fences. In North Garo Hills, Meghalaya, NE India, Grevillea robusta bark and leaves used for headaches and dizziness ${ }^{4}$. In Kenya, natives of the Kakamega forest use the plant to treat sore throats, earache, chest problems, flu and toothache. Present study is therefore aimed to explore Grevillea robusta as traditionally it is used as antiinflammatory agent. Therefore, the present study is aimed for pharmacological evaluation of Grevillea robusta leaves ethanolic extract for anti-inflammatory potential.

\section{MATERIALS AND METHODS}

\section{Collection and authentication}

Fresh leaves of Grevelliea robusta were collected from Dev Bhoomi Institute of Pharmacy and Research, Dehradun and were authenticated by Botanical Survey of India, Northern Regional Centre by matching the sample with BSD student herbarium (Acc. No. 112) vide letter number BSI/NRC...Tech./Herbs(Indent.)/2019-20. The leaves were dried in shade and powdered to a coarse form. The leaves were carefully checked for the presence of any foreign matter.

\section{Quantitative Investigation}

The ash values, loss on drying and extractive values of the powdered samples were performed to evaluate the samples quantitatively ${ }^{5,6,7}$.

a. Determination of Ash values and loss on drying: Ash values (Evans, 1996) and Loss on drying (WHO Guide line) 
of Grevelliea robusta leaves were also determined to check the purity of the sample.

b. Preparation and extract: Extracts were prepared by the cold maceration method for $48 \mathrm{~h}$ using petroleum ether, toluene, ethyl acetate and ethanol (Sample: Solvent ratio:: 1:10). The extracts were evaporated to dryness using rotary evaporator and corresponding extractive values were determined.

\section{Phytochemical Evaluation}

All extracts were subjected to phytochemical evaluation for flavonoids, alkaloids and terpenoids using the methods as described by Evans, 1996.

\section{Pharmacological Evaluation}

The extracts of Grevelliea robusta leaves were evaluated 8,9 for Anti- inflammatory activity by two methods:

a. The human red blood cell (HRBC) membrane stabilization method: The membrane stabilization with Grevelliea robusta leaves extracts were evaluated through their capacity to resist hypotonic solutioninduced hemolysis of human erythrocytes following the method developed by Omale et al. (2008).

b. Heat induced hemolytic method: Grevelliea robusta leaves extracts were evaluated through their capacity to resist heat- induced hemolysis of human erythrocytes following the method prescribed by Omale et al. (2008)

\section{RESULTS AND DISCUSSION}

\section{Quantitative Investigation}

a. Determination of Ash values and loss on drying The percentage of total ash, water-soluble ash, acidinsoluble ash, and Sulfated ash values for Grevillea robusta leaves are listed in [Table 1].

b. Preparation and extract: Extractive values of the sample in petroleum ether (GRLPE), toluene (GRLT), ethyl acetate (GRLEa), ethanol (GRLT) and water (GRLW) are tabulated in [Table 2].
These data may be utilized for setting the pharmacognostic standard of Grevillea robusta leaves.

Table 1: Evaluation of Loss on drying and different ash values of the dried powdered Grevillea robust leaves

\begin{tabular}{|l|c|}
\hline Evaluation parameters & $\begin{array}{c}\text { Value }(\% \mathbf{w} / \mathbf{w}) * \\
\text { (Leaves) }\end{array}$ \\
\hline Loss on drying & $4.95 \pm 0.86$ \\
\hline Total ash value & $1.34 \pm 0.24$ \\
\hline Water-soluble ash value & $0.86 \pm 0.11$ \\
\hline Acid-insoluble ash value & $0.31 \pm 0.09$ \\
\hline Sulfated ash value & $0.34 \pm 0.07$ \\
\hline
\end{tabular}

* Mean value of five counts.

Table 2: Evaluation of different extractive values of dried powdered leaves of Grevillea robusta leaves

\begin{tabular}{|l|c|}
\hline Evaluation parameters & Values $(\% \mathbf{w} / \mathbf{w}) *$ \\
\hline Petroleum ether extractive value & $1.7 \pm 0.69$ \\
\hline Toluene extractive value & $2.9 \pm 0.36$ \\
\hline Ethyl acetate extractive value & $16.9 \pm 0.58$ \\
\hline Ethanol extractive value & $45.6 \pm 0.32$ \\
\hline Water extractive value & $11.09 \pm 0.32$ \\
\hline
\end{tabular}

* Mean value of five counts.

\section{Phytochemical Evaluation}

The chemical constituent of extract was found to be maximum in case of GRLE and minimum in case of GRLT and GRLPE [Table 3]. GRLE and GRLEa contained good amount of Tannins, Flavonoids and Saponins. GRLW contain no flavonoid and saponins.

Table 3: Phytochemical screening of extracts of Grevillea robusta leaves.

\begin{tabular}{|l|l|c|c|c|c|}
\hline S.N. & Test & $\begin{array}{c}\text { Toluene extract } \\
\text { (GRLT) }\end{array}$ & $\begin{array}{c}\text { Ethyl acetate extract } \\
\text { (GRLEa) }\end{array}$ & $\begin{array}{c}\text { Ethanol extract } \\
\text { (GRLE) }\end{array}$ & $\begin{array}{c}\text { Water extract } \\
\text { (GRLW) }\end{array}$ \\
\hline 1. & Carbohydrates & + & + & + & + \\
\hline 2. & Alkaloids & - & + & + & + \\
\hline 3. & Tannins & - & + & + & - \\
\hline 4. & Flavonoids & + & + & + & - \\
\hline 5. & Saponins & - & + & - & - \\
\hline 6. & Glycosides & + & - & + & + \\
\hline 7. & Mucilage & - & + & + & + \\
\hline
\end{tabular}




\section{Pharmacological Evaluation}

It was observed that GRLE and GRLEa at the concentration of $100 \mu \mathrm{g} / \mathrm{ml}$ exhibited $79.33 \%$ and 76.66\% HRBC membrane stabilization activity respectively [Table 4]. Heat induced hemolytic inhibitions of GRLE and GRLEa at a concentration $100 \mathrm{\mu g} / \mathrm{ml}$ were $88.42 \%$ and $76.32 \%$ respectively [Table 5]. GRLW did neither produced any HRBC membrane stabilization activity nor Heat induce hemolytic inhibition which emphasize the fact flavonoid may be responsible chemical constituent for antiinflammatory activity.

Table 4: HRBC membrane stabilization with different extract of Grevillea robusta leaves

\begin{tabular}{|l|l|c|c|}
\hline $\mathbf{S}$. & $\begin{array}{l}\text { Type of } \\
\text { extract }\end{array}$ & $\begin{array}{c}\text { Concentration } \\
(\mu \mathrm{g} / \mathrm{ml})\end{array}$ & \% Inhibition \\
\hline 1 & Control & - & - \\
\hline 2 & GRLT & 50 & $43.33 \pm 0.60$ \\
\hline 3 & GRLT & 100 & $52.66 \pm 0.37$ \\
\hline 4 & GRLEa & 50 & $54.66 \pm 0.25$ \\
\hline 5 & GRLEa & 100 & $76.66 * * 0.33$ \\
\hline 6 & GRLE & 50 & $66.66 \pm 0.21$ \\
\hline 7 & GRLE & 100 & $79.33 * * \pm 0.14$ \\
\hline 8 & GRLW & 50 & - \\
\hline 9 & GRLW & 100 & - \\
\hline 10 & Diclofenac & 100 & $97.66 \pm 0.16$ \\
\hline & sodium & & \\
\hline
\end{tabular}

Table 5: Heat induce hemolytic inhibition of different extract of Grevillea robusta leaves

\begin{tabular}{|l|l|c|c|}
\hline $\mathbf{S}$. & $\begin{array}{l}\text { Type of } \\
\text { extract }\end{array}$ & $\begin{array}{c}\text { Concentration } \\
(\mu \mathrm{g} / \mathrm{ml})\end{array}$ & \% Inhibition \\
\hline 1 & Control & - & - \\
\hline 2 & GRLT & 50 & $46.84 \pm 0.44$ \\
\hline 3 & GRLT & 100 & $51.63 \pm 0.34$ \\
\hline 4 & GRLEa & 50 & $55.26 \pm 0.21$ \\
\hline 5 & GRLEa & 100 & $76.32 * * \pm 0.19$ \\
\hline 6 & GRLE & 50 & $47.89 \pm 0.17$ \\
\hline 7 & GRLE & 100 & $88.42 * * \pm 0.21$ \\
\hline 8 & GRLW & 50 & - \\
\hline 9 & GRLW & 100 & - \\
\hline 10 & Diclofenac & 100 & $98.95 \pm 0.10$ \\
\hline & Sodium & & \\
\hline
\end{tabular}

GLRE produced significant anti-inflammatory activity compared to the control in concentration depended on fashion and activity is almost comparable to well known synthetic NSAID Diclofenac Sodium $(100 \mu \mathrm{g})$. This result is in conformation with result of Ullah et al, 2014. Flavonoid present in the extract may be responsible chemical constituents for anti-inflammatory potential of GLRE.

\section{CONCLUSION}

In present study, the anti-inflammatory potential of various extract of Grevillea robusta leaves was studied. GRLE was found to be more potent than other extracts. GRLW was devoid of anti-inflammatory potential. GRLE possessed flavonoid and saponins as additional phytoconstituents than Water extract. On basis of the result, it was concluded that leaves of Grevillea robusta had significant antiinflammatory activity. The activity may be attributed through flavonoids. Isolation of the chemical constituents responsible for above activities and semi synthetic modification for target specific anti-inflammatory activity may be the next research area. Safe and Economical antiinflammatory agents could be formulated from Grevillea robusta leaves.

\section{REFERENCES}

1. Harsh Mohan. Inflammation and healing, Textbook of pathology; $5^{\text {th }}$ ed. Vol. 6. New Delhi: Jaypee Brothers Medical Publishers (P) Itd. 2005;133-134

2. Peskar, B. A., Steffens, Ch., Peskar, B. M.: Radioimmunoassay of 6-keto-prostaglandin $F_{1 \alpha}$ in biological material. In: Radioimmunoassay of drugs and hormones in cardiovascular medicine (A. Albertini, M. Da Prada, B. A. Peskar, eds.), Amsterdam: ElsevierNorth Holland Publ. Co. 1979; 239-250.

3. Inger L. Meek, Mart A.F.J. van de Laar, and Harald E. Vonkeman. Non-Steroidal Anti-Inflammatory Drugs: An Overview of Cardiovascular Risks. Pharmaceuticals (Basel). 2010; 3(7): 2146-2162.

4. Sharma M, Sharma CL and Marak PN. Indigenous uses of medicinal plants in North Garo Hills, Meghalaya, NE India. Res. J. Recent. Sci. 2014;3(ISC-2013): 137-146

5. Evans WC. Trease and Evans' Pharmacognosy. $14^{\text {th }}$ ed. London: WB Sounders Company Ltd.1996; 545-546.

6. Kokate CK. Practical Pharmacognosy. $4^{\text {th }}$ ed. New Delhi, India: Vallabh Prakashan. 1994; 112-120.

7. Quality Control Methods for Medicinal Plant Materials World Health Organization (Geneva) Delhi: AITBS Publishers and Distributor.2004; 28-30.

8. Omale J and Okafor PN. Comparative antioxidant capacity, membrane stabilization, polyphenol composition and cytotoxicity of the leaf and stem of Cissus multistriata. African Journal of Biotechnology. 2008; 7 (17):3129-3133.

9. Ullah MS, Sikder MAA, Sharmin T and Rashid MA. Pharmacological Activities of Grevillea robusta, a Medicinal Plant of Bangladesh. Bangladesh Pharmaceutical Journal. 2014; 17(2): 135-137. 
10. Rashida Ginwala, Raina Bhavsar, DeGaulle I. Chigbu, Pooja Jain and Zafar K. Khan. Potential Role of Flavonoids in Treating Chronic Inflammatory Diseases with a Special Focus on the Anti-Inflammatory Activity of Apigenin. Antioxidants. 2019;8(35):1-30.

\begin{tabular}{|l|}
\hline Source of Support: None declared. \\
\hline Conflict of Interest: None declared. \\
\hline For any question relates to this article, please reach us at: editor@globalresearchonline.net \\
New manuscripts for publication can be submitted at: submit@globalresearchonline.net and submit_ijpsrr@rediffmail.com \\
\hline
\end{tabular}

\section{Corresponding Author Biography: Dr. Jhuma Samanta}

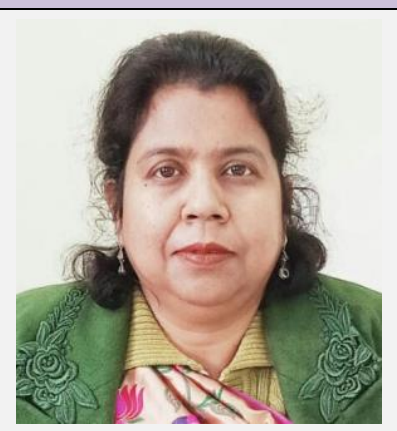

Dr. Jhuma Samanta is Professor and Research Head in the Department of Pharmacy, Shree Dev Bhoomi Institute of Education, Science and Technology, Dehradun. She is associated with pharmaceutical industry, academics and research for last 17 years. Since 2010, she worked as HOD (Pharmaceutical Chemistry) in University School of Pharmacy in Rayat Bahra University, Mohali, Punjab.

Since August'2018 to May '2020she worked as Director in a Dev Bhoomi Institute of Pharmacy and Research. She worked as a Sr. Scientist in DNA Lab- A Centre for Applied Sciences, Dehradun.

Her educational qualification is M. Pharm (Pharmaceutical Chemistry) and Ph. D (Pharmacy). She is national scholarship owner, qualified GATE and NIPER Ph. D entrance. She has been awarded as Women Scientist (Pharmacy) in 2020 and received Research Excellence Award in 2021.

She is reviewer of International Journal of Pharmacy and Chemistry and International Journal of Basic and Applied Sciences. Fetching financial Assistance/Grant from UCOST and USERC, Uttarakhand is in her credential.

Her primary research area is anti-fertility agents. Her other research is on antifungal agents and anti-inflammatory agents, proteolytic enzyme, kinetic and thermodynamic aspects of enzyme substrate reaction etc. She is desired to precede her further research in molecular level to develop economic biologics to control fertility, treat cancer and menopausal syndrome. Drug discovery, mode of action and pharmacokinetics are area of lecture delivery since last 15 year. She published 44 scientific papers and two books (1published and 1-under process).

She is an assertive and enthusiastic; dedicated and effective researcher with extensive knowledge of process optimization and unsuppressed work ethics. 